\title{
Rapid mass propagation of endangered valuable medicinal plant Salacia chinensis L. and GC- MS/LC-MS analysis of active compounds produced in callus and leaf extracts
}

Kamat, S.G ${ }^{1}$, Vasudeva, R²., Patil, C. G. ${ }^{3 *}$

${ }^{1}$ Department of Applied Genetics, Karnataka University, Dharwad, India

${ }^{2}$ Department of Forest Biology and Tree Improvement, University of Agricultural Sciences, Dharwad, College of Forestry, Sirsi, India.

3*Department of Botany, Karnataka Science College, Dharwad, India. Patilcg1970@gmail.com

\begin{abstract}
A protocol for indirect organogenesis of Salacia chinensis was established. Normally $S$. chinensis is propagated through seeds. However, due to the difficulty to obtain uniform plants in a short time period by seed germination, micro-propagation is a possible alternative method. For the micro-propagation, media with different concentration combinations of cytokinins and auxins were used to induce callus formation in three explants types: leaf segment, nodal segment and seeds. The rate of recurrence of callus formation from leaf on Murashige and Skoog (MS) basal medium supplemented with thidiazuron (TDZ) $0.5 \mathrm{mg}$ and TDZ $1 \mathrm{mg}$ was $100 \%$ and the maximum percentage of shoot let development from nodal segment on MS basal medium supplemented with BAP 6(benzylamino purine) $3.5+$ indole3-butyric acid (IBA) $1 \mathrm{mg} / 1$ was $78.3 \%$ when compared to other plant growth regulators (PGR) combinations used. The highest shoot regeneration response $(85 \%)$ and the determined shoots $(12.33 \pm 0.33 \%)$ per callus were attained from leaf explants on MS medium containing 1-napthaleneacetic acid (NAA) 1mg/1 + BAP 0.5 $\mathrm{mg} / \mathrm{l}$. The seeds showed highest percentage of shoot formation on MS medium supplemented with BAP $2 \mathrm{mg}+$ indole 3 -acetic acid (IAA) $2 \mathrm{mg} / 1$ and BAP $2 \mathrm{mg}+$ isopentenyl adenine (2iP) $2 \mathrm{mg} / \mathrm{l}$. Highest root formation $(70 \pm 1.3 \%$ ) was found in shoot regenerated using leaf segment on MS medium supplemented with IBA $0.5 \mathrm{mg}$. The gas chromatography mass spectrometry (GC-MS) analysis of methanolic extract of callus showed more compounds at higher percentage. HPLC-MS analysis of methanolic extract of callus showed higher concentration of Mangifera than in leaf extracts are reported for the first time.
\end{abstract}

Received: 07 Jan 2021

Accepted: 01 Apr 2021

Key words:

callus induction

Mangifera

micro-propagation

secondary metabolites

*Corresponding author:

Patilcg1970@gmail.com sheetalkamat7@gmail.com

\section{Introduction}

Salacia chinensis L. is a medicinally important plant used as herbal medicine in Ayurveda (Ghanam et al., 2016) and different parts of this plant have been extensively used to treat variety of ailments (Sikarwar et al., 2012). Biologically active compounds such as mangiferin, salacinol, kotanalol, phenolic compounds, glycosides and triterpenes have been isolated from the plant (Matsuda et al.,

2005). For the treatment of diabetes, the compound Salacinol along with other compounds, present in $S$. chinensis is increasingly being used (Patwardhan et

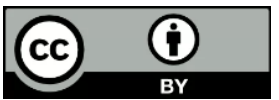

This is an open-access article distributed under the terms of the Creative Commons Attribution 4.0 International License, which permits unrestricted use, distribution and reproduction in any medium provided the original author and source are credited. 
al., 2014). Extracts of $S$. chinensis have preventive effect on various metabolic disorders (Waltenberger et al., 2016).

Due to the lack of proper cultivation practices, devastation of plant habitats, excessive and unselective collection to fulfil global demands, especially for its anti-diabetic property, this medicinal plant is severely threatened and categorized as endangered species (Bhagya et al., 2011, Maheswari et al., 2016, Majid et al., 2016, florakarnataka.ces.iisc.ac.in., www.iucnredlist.org 2015). There is a need for its conservation and largescale production. Very little efforts have been reported on propagation (Dhanasri et al., 2015; Majid et al., 2016). In this study, we report a reproducible and reliable micro-propagation protocol developed for its effective propagation.

\section{Materials and Methods}

\subsection{Explants source and surface sterilization}

Young and healthy leaves and nodal segments were collected from four- year old $S$. chinensis plants maintained in Botanical garden of College of Forestry, Sirsi and seeds were collected from Amruta herbals, Bargal Karwar. The undamaged collected explants were washed thrice under running tap water and were pre-washed with concentrated dish washer gel (Sodium LAS, Disodium EDTA, SLES, Concentrated Lime Juice, CI 19140, CI 42051, Water) (4-5drops/100ml double distilled water $\left(\mathrm{ddH}_{2} \mathrm{O}\right)$ for 5 minutes followed by rinsing five times in $\mathrm{ddH}_{2} \mathrm{O}$. Subsequently, the explants were submerged in $70 \%(\mathrm{v} / \mathrm{v})$ ethanol for 2 minutes. Nodal segments were surface sterilized with $0.1 \%$ of mercuric chloride $\left(\mathrm{HgCl}_{2}\right)$ while leaf explants were sterilized with $1.0 \%(\mathrm{w} / \mathrm{v})$ of Sodium hypochlorite
$(\mathrm{NaOCl})$ plus Tween 20 (2-3 drops/100ml dd $\mathrm{H}_{2} \mathrm{O}$ ) and seeds were sterilized in $2 \% \mathrm{NaOCl}$ solution for 15 minutes. The solutions were discarded and surface sterilized explants were washed thoroughly with $\mathrm{ddH}_{2} \mathrm{O}$ for four times under aseptic conditions and placed on a sterilized petridish covered with autoclaved filter paper to remove excess moisture.

\subsection{Medium composition and culture conditions}

Basal medium used for inoculation was Murashige and Skoog's medium (MS) (Murashige and Skoog 1962 ) supplemented with $3 \%(\mathrm{w} / \mathrm{v})$ sucrose and $0.8 \%$ agar. The $\mathrm{pH}$ of the medium was adjusted to 5.7 before autoclaving at $121^{\circ} \mathrm{C}$ at 15 psi pressure for $20 \mathrm{~min}$ for medium sterilization. The explants were cut into suitable sized pieces $(1.0 \mathrm{~cm}$ for leaf and $1.5 \mathrm{~cm}$ for nodal segment). Each excised explant was incubated in pre-sterilized test tubes, petridishes or suitable containers containing $20 \mathrm{ml}$ medium supplemented with various combinations of auxins and cytokinins.

\subsection{Preparation of stock solutions of plant growth hormones (PGRs)}

The desired PGRs stock solutions $(1.0 \mathrm{mg} / \mathrm{l})$ were prepared by weighing $13 \mathrm{mg}$ of desired PGR dissolving in $13 \mathrm{ml}$ of $\mathrm{ddH}_{2} \mathrm{O}$ with the help of respective solvents (Table 1 ). The stock solutions were stored in micro centrifuge tubes at suitable temperature (at $4^{\circ} \mathrm{C}$ ). IAA was stored in amber coloured bottle in order to prevent photodecomposition.

\subsection{Incubation conditions}

Cultures were incubated at temperature of $25 \pm 2{ }^{\circ} \mathrm{C}$, air humidity of $55 \%$ and a 16 -h photoperiod supplied by cool-white florescent tubes.

Table 1: Preparation growth hormone

\begin{tabular}{|c|c|c|c|}
\hline Sl. No & PGRs & Solvents & Storage conditions \\
\hline 1 & indole-3-acetic acid (IAA) & $95 \%$ ethanol or $\mathrm{KOH}$ & At $-20^{\circ} \mathrm{C}$ indefinitely \\
\hline 2 & indole-3-butyric acid (IBA) & $1 \mathrm{~N} \mathrm{NaOH}$ or $\mathrm{KOH}$ & At $-20^{\circ} \mathrm{C}$ indefinitely \\
\hline 3 & $\begin{array}{l}\text { 2,4-dichlorophenoxy acetic } \\
\text { acid }(2,4-D)\end{array}$ & $1 \mathrm{~N} \mathrm{NaOH}$ or $\mathrm{KOH}$ & $\begin{array}{l}\text { At } 4^{\circ} \mathrm{C} \text { for several months or At }-20^{\circ} \mathrm{C} \\
\text { indefinitely }\end{array}$ \\
\hline 4 & $\begin{array}{l}\text { 1-napthaleneacetic acid } \\
\text { (NAA) }\end{array}$ & $95 \%$ ethanol, $1 \mathrm{~N} \mathrm{NaOH}$ or $\mathrm{KOH}$ & $\begin{array}{l}\text { At } 4^{\circ} \mathrm{C} \text { for several months or At }-20^{\circ} \mathrm{C} \\
\text { indefinitely }\end{array}$ \\
\hline 5 & 6-benzylamino purine (BAP) & $0.1 \mathrm{~N} \mathrm{HCl}$ or $95 \%$ ethanol & $\begin{array}{l}\text { At } 4^{\circ} \mathrm{C} \text { for several months or At }-20^{\circ} \mathrm{C} \\
\text { indefinitely }\end{array}$ \\
\hline
\end{tabular}

\subsection{Tissue culture studies:}

\subsubsection{Direct regeneration:}

Shoot differentiation and shoot proliferation and rooting of regenerated shoots from nodal segment explant and seed:
Surface sterilized nodal explants were inoculated on MS medium supplemented with different growth regulators viz., gibberellic acid $\left(\mathrm{GA}_{3}\right)$ (1-3mg/l), TDZ (1-3mg/l) + kinetin (Kn) (0.5-1mg/l), Bap (1$4 \mathrm{mg} / \mathrm{l})+\mathrm{IBA}(1 \mathrm{mg} / \mathrm{l})$, BAP $(1-4 \mathrm{mg} / \mathrm{l})+\mathrm{IAA}$ $(1 \mathrm{mg} / \mathrm{l}), \mathrm{Kn}(2.5-4 \mathrm{mg} / \mathrm{l})+\mathrm{IBA}(0.5-1 \mathrm{mg} / \mathrm{l}), \mathrm{Kn}(2.5-$ 
$4 \mathrm{mg} / \mathrm{l})+$ IAA $(0.5-1 \mathrm{mg} / \mathrm{l})$, polyvinylpyrolidine $(0.1 \%)$, L-Proline $(0.1 \%)$ and activated charcoal $(0.1 \%)$ were added to MS media to inhibit formation and release of phenolic into media. The shoots longer than $3 \mathrm{~cm}$ were excised from the axils and transferred into half strength MS rooting medium, supplemented with or without IAA $(0.5-2 \mathrm{mg} / \mathrm{l})$, IBA $(5-15 \mathrm{mg} / 1)$, NAA $(5-15 \mathrm{mg} / \mathrm{l})$. After root initiation, micro shoots were transferred to half strength MS medium supplemented with IAA $(2.0 \mathrm{mg} / \mathrm{l})$ for normal growth of roots.

Seed explants were inoculated on MS medium supplemented with different combinations of PGR's (Table 1). Treatments were arranged in a completely randomized design 20 seeds per treatment one seed/tube and the experiment was repeated thrice.

\subsubsection{Indirect organogenesis:}

Callus induction, shoot differentiation, shoot proliferation and rooting of regenerated shoots from leaf explant:

For callus induction, the excised healthy mature leaves were inoculated on MS medium supplemented with different growth regulators viz., 0.5 or $2.0 \mathrm{mg} / 1$ Indole-3-butyric acid (IBA) or $\alpha$ naphthalene acetic acid (NAA) or 2,4dichlorophenoxyacetic acid (2,4-D) or 6benzylaminopurine (BAP) or thidiazuron (TDZ) or $6-(\gamma-\gamma$, dimethylallyamino purine) (2iP). Leaf explants were cultured on the media in a growth chamber at $25^{\circ} \mathrm{C}$ under $16 \mathrm{~h}$ light $/ 8 \mathrm{~h}$ dark photoperiod provided by white fluorescent tubes. Effect of various auxin/cytokinins on callus induction was evaluated based on the appearance and consistence of callus formation in each treatment. After 4- weeks of callus induction, only well-developed regenerating calli (2-3 mm diameter pieces) were transferred to half strength MS media supplemented with $0.5-1.0 \mathrm{mg} / \mathrm{l} \quad \mathrm{NAA}$ in combination with $0.5-1.0 \mathrm{mg} / 1 \mathrm{iP}$ or $0.5-1.0 \mathrm{mg} / 1$ TDZ or $0.5-1.0 \mathrm{mg} / 1$ BAP. The regenerating callus cultures were maintained in growth chambers on the same medium with controlled conditions for 8 weeks for shoot induction. There were four replicate culture flasks with 5 explants each per treatment and the experiment was repeated thrice. The mean percentage of shooting response, mean number of shoot buds formed, mean shootlet length and mean number of leaves per callus were recorded after 90 days of subculture. Two-three $\mathrm{cm}$ long shoots were isolated from shoot clusters from elongation medium and transferred individually to half strength MS medium supplemented with IBA, NAA or IAA $(0.5-2 \mathrm{mg} / \mathrm{l})$ and incubated for 4 weeks for root development. After root initiation micro shoots were transferred to half strength MS medium supplemented with IAA $(2.0 \mathrm{mg} / \mathrm{l})$ for normal growth of roots.

\subsection{Preparation of leaf extract for GC-MS and HPLC-MS analysis:}

The fine powdered granules from shade dried leaves of $S$. chinensis were subjected to extraction. In 400$500 \mathrm{ml}$ methanol about $30 \mathrm{~g}$ of dried powdered granules were soaked and extracted at temperature between $60-65{ }^{\circ} \mathrm{C}$ by continuous hot percolation method using Soxhlet apparatus. The extraction was continued for 72 hours. The extract was then filtered and concentrated using rotary evaporator to the volume of $25 \mathrm{ml}$. The dark yellowish brown concentrate was obtained (Jayaraj et al., 2016). This concentrate was used for phytochemical analysis using Gas chromatography mass spectrometry (GCMS). The dark yellowish brown concentration was further dried to obtain powder which was used for High performance liquid chromatography mass spectrometry (HPLC-MS) technique analysis of mangiferin concentration in root and stem samples (Dhanasri et al., 2015). The experiments were repeated three times.

\subsubsection{Preparation of leaf extract for GC-MS and HPLC-MS analysis:}

Callus was dried at $40^{\circ} \mathrm{C}$ for $24 \mathrm{hrs}$, ground into powder using mortar and pestle, then subjected to extraction. About $30 \mathrm{~g}$ of callus powder was extracted with $400-500 \mathrm{ml}$ methanol using Soxhlet apparatus for 72 hours at $60^{\circ} \mathrm{C}$. The solution was then evaporated to dryness as mentioned in 2.6, and then the extract was stored at $4^{\circ} \mathrm{C}$ for future use.

\subsubsection{Mangiferin concentration analysis of leaf and callus developed from leaf explant:}

In this study we have analysed the phytoconstituents using GC-MS MS (Shimadzu model number QP2010S) equipped with Rxi- 5Sil MS fused silica capillary column $(30 \mathrm{~m} \mathrm{X} 0.25 \mathrm{~mm}$ ID, film thickness $0.25 \mu \mathrm{m}$ ). As carrier gas pure helium gas was used at constant flow rate of $\pm 1 \mathrm{~mL} / \mathrm{min}$. Injector temperature was set at $260{ }^{\circ} \mathrm{C}$. The oven temperature was programmed initially at $80^{\circ} \mathrm{C}$ and then programmed to increase at $280^{\circ} \mathrm{C}$ at a rate of $10^{\circ} \mathrm{C}$ ending with a $20 \mathrm{~min}$. The spectrums of the components were compared with database of spectrum of known components stored in GC MS libraries NIST 11 \& WILEY 8. Measurement of peak areas and data processing were carried out by GC MS solutions software (Sivakumar \& Dhivya 2015).

The concentration of mangiferin was determined using HPLC-MS (Shimadzu LC-10 AT vp) equipped with luna $5 \mathrm{u}$ C18 analytical column (250 x 
$4.6 \mathrm{~mm})$ and SPD-M10A vp photo diode array detector (PDA). Mobile phase used for mangiferin quantification was A: Acetonitrile (15\%) and B: $0.1 \%$ Ortho Phosphoric acid $(85 \%)$. The $20 \mu 1$ (1mg sample dissolved in $1 \mathrm{ml}$ methanol) of sample was injected for flow of $1 \mathrm{ml} / \mathrm{min}$ with total $12 \mathrm{~min}$ run time at wavelength of $257 \mathrm{~nm}$. Calibration was carried out using standard Mangiferin (Jayaraj et al., 2016) in callus part derived from leaf explant for comparative analysis of mangiferin between plants collected naturally and callus culture of $S$. chinensis.

\subsection{Statistical analysis:}

All the experiments described above were conducted in a completely randomized design and repeated thrice. All the tissue culture experiments such as callus induction, shoot regeneration, shoot number and shoot length under different plant growth regulator concentrations were computed and analysis of variance (ANOVA) was used for data analysing using the IBM SPSS statistical package (Version 20.0. Armonk, NY, USA:IBM Corp.) The significant differences between means were scored using Duncan's Multiple Range Test $(P=0.05)$.

\section{Results}

3.1 Leaf explants:

Leaf, nodal and seed explants cultured on MS medium without PGRs failed to produce shoots even after 4 weeks of inoculation. Whereas swelling and expansion was observed in MS medium supplemented with PGR's and callus induction was started at the cut ends after 6-7 days of incubation of leaf segment explants of $S$. chinensis. Two types of calli were formed at the cut ends of leaf explants. One comprises of soft, white calli and the other has nodular, greenish white calli (Plate 1a). The maximum frequency $(100 \%)$ of callus formation was observed with explants supplemented with TDZ (0.5 and $1 \mathrm{mg} / \mathrm{l}$ ) compared to other PGRs. Callus induction was decreased when higher concentration of PGRs were used. The callus obtained was regularly sub cultured on fresh medium with the same PGR concentration. The callus thus formed was transferred to regeneration medium (plate $1 \mathrm{~b}-\mathrm{d}$ ). Maximum rooting $(8.5 \pm 0.28 \%)$ was observed on half strength MS medium supplemented with IAA $0.5 \mathrm{mg} / \mathrm{l}$. The different PGRs treatments used and mean percentage of callus induction was represented in table 2 .

Table 2: In vitro response of leaf explants to various concentration of plant growth hormones (PGR)

\begin{tabular}{|c|c|c|c|c|c|c|c|}
\hline \multicolumn{6}{|c|}{$\begin{array}{l}\text { Concentration of plant } \\
\text { growth regulators (PGRs) mg/l }\end{array}$} & \multirow[t]{2}{*}{$\begin{array}{l}\text { No. of explants } \\
\text { inoculated }\end{array}$} & \multirow[t]{2}{*}{$\begin{array}{l}\text { Mean percentage of } \\
\text { Callus induction }(\%)\end{array}$} \\
\hline BAP & TDZ & $2,4 \mathrm{D}$ & IBA & $2 \mathrm{iP}$ & NAA & & \\
\hline 0 & 0 & 0 & 0 & 0 & 0 & 20 & 0.0 \\
\hline 0.5 & - & - & - & - & - & 20 & 65 \\
\hline 1 & - & - & - & - & - & 20 & 70 \\
\hline 2 & - & - & - & - & - & 20 & 55 \\
\hline- & 0.5 & - & - & - & - & 20 & 100 \\
\hline- & 1 & - & - & - & - & 20 & 100 \\
\hline- & 2 & - & - & - & - & 20 & 90 \\
\hline- & - & 0.5 & - & - & - & 20 & 35 \\
\hline- & - & 1 & - & - & - & 20 & 40 \\
\hline- & - & 2 & - & - & - & 20 & 30 \\
\hline- & - & - & 0.5 & - & - & 20 & 0.0 \\
\hline- & - & - & 1 & - & - & 20 & 25 \\
\hline- & - & - & 2 & - & - & 20 & 15 \\
\hline- & - & - & - & 0.5 & - & 20 & 50 \\
\hline- & - & - & - & 1 & - & 20 & 55 \\
\hline- & - & - & - & 2 & - & 20 & 45 \\
\hline- & - & - & - & - & 0.5 & 20 & 40 \\
\hline- & - & - & - & - & 1 & 20 & 42.5 \\
\hline- & - & - & - & - & 2 & 20 & 35 \\
\hline
\end{tabular}




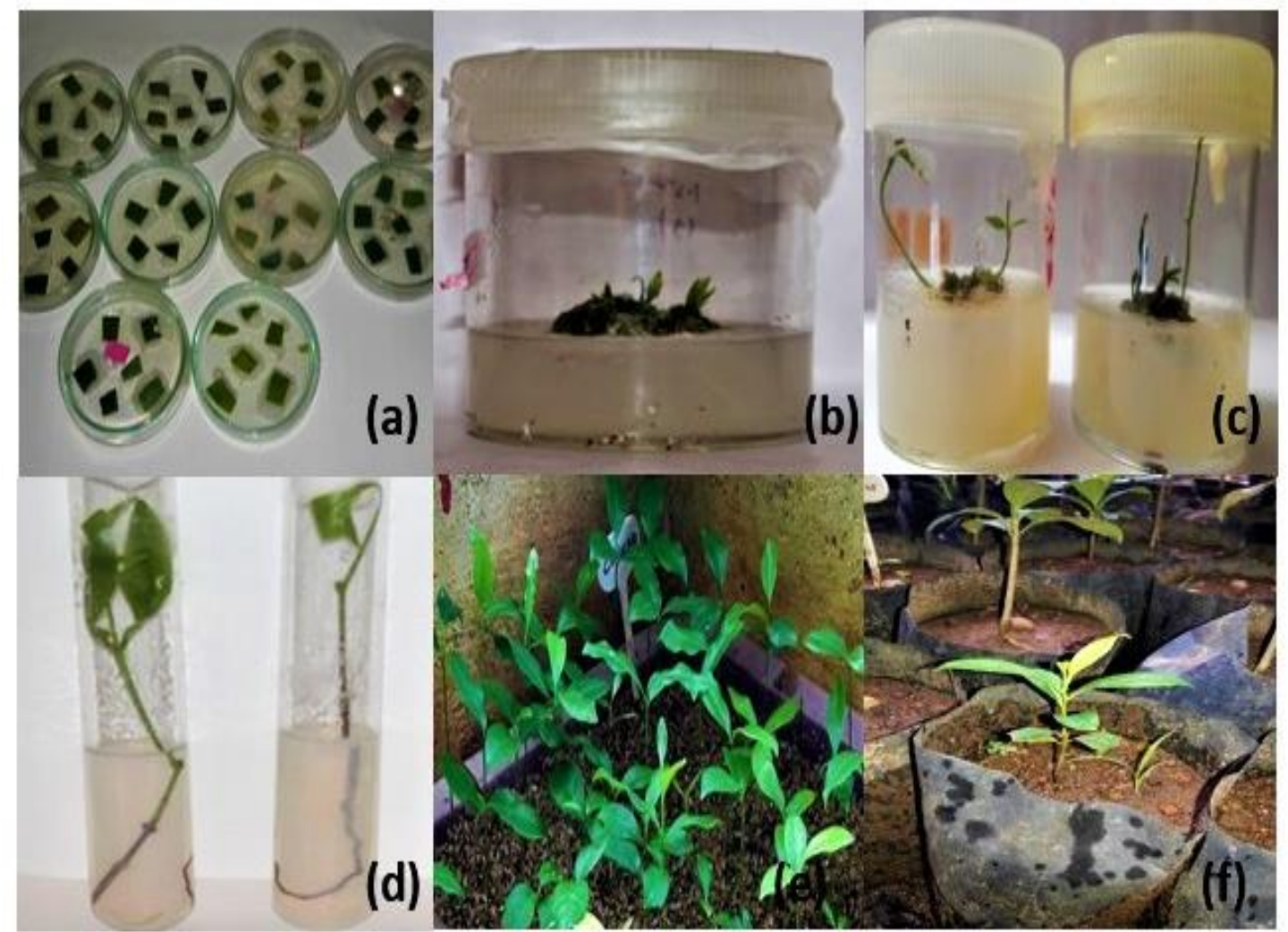

Plate 1: Callus morphogenesis and shoot bud regeneration of Salacia chinensis: (a) The induced leaf callus tissue on MS medium supplemented with TDZ (0.5mg/l) (b) Adventitious shoot bud regeneration with primary callus (c) Emerging of multiple shoots (d) rooting of the regenerated shootlet (e) Hardening of explant bio compost nutrients f) Hardened plantlets with thick roots were transferred into polythene bags containing bio compost nutrients

\subsubsection{Regenerating callus and shoot:}

Soft, green nodular organogenic callus sub-cultured on MS medium with different combinations of BAP, TDZ and IBA in combination with NAA $(0.5-1 \mathrm{mg} / \mathrm{l})$ produced embryogenic callus and shoots were induced after few days. Maximum shoot regeneration was observed when callus cultured on MS medium supplemented with BAP (1.0mg/l) along with NAA $(0.5 \mathrm{mg} / \mathrm{l})$. Responses of different concentration of PGRs on shoot bud regeneration from callus cultures, mean of shooting response, mean number of shoot buds observed and mean height of shootlet of $S$. chinensis were listed in Table 3. Elongated shoots were then transferred to half strength MS medium containing different concentration of PGR's i.e., IBA, IAA or NAA (0.5$1 \mathrm{mg} / \mathrm{l})$ (Table 4).

\subsection{Nodal explants:}

Nodal explants cultured for regeneration, on full strength MS medium supplemented with different combinations of PGRs i.e. high concentration of $\mathrm{GA}_{3}(2-3 \mathrm{mg} / \mathrm{l}), \mathrm{TDZ}+\mathrm{Kn}(1-3+0.5 \mathrm{mg} / \mathrm{l}), \mathrm{Kn}+\mathrm{IBA}$ $(2.5-3+0.5-1 \mathrm{mg} / \mathrm{l}), \mathrm{Kn}+\mathrm{IAA}(2-3+0.5-1 \mathrm{mg} / \mathrm{l})$ showed significant changes in the first week of inoculation i.e., small protuberance. Plate 2 shows different stages of micro propagation of $S$. chinensis $\mathrm{L}$ nodal explants. The percentage of explants showing the same response at the axils is more or less similar in all the PGRs combinations used. The sprouts in the axils increased in size to form shootlets in 2 weeks. The maximum percentage of shootlets development was observed on the phytohormones combinations BAP $3.5 \mathrm{mg} / 1$ with combination of IBA $1 \mathrm{mg} / 1(78.3 \%)$ and BAP $3 \mathrm{mg} / 1$ with combination of IAA $1 \mathrm{mg} / 1 \quad(43 \%)$ when compared to other PGRs combinations used. Full strength medium supplemented with $\mathrm{GA}_{3}$ (0.5$1.5 \mathrm{mg} / \mathrm{l})$ induced shoots but the shoots were dwarf.

Full strength medium supplemented with different concentration of BAP in combination with IAA or IBA induced shoot formation but BAP $3.5 \mathrm{mg}+$ IBA $1 \mathrm{mg}$ gave better results in regeneration of number of shoots $15 \pm 0.6$ and enhancement of shoot elongation (table 5, Plate 2b). The shootlets increased in length during the $3^{\text {rd }}$ week and the maximum shoot length of $2.83 \pm 0.44$ was observed in BAP $3.5 \mathrm{mg} / 1$ + IBA $1 \mathrm{mg} / 1$. 
Table 3: Responses of different concentration of plant growth regulators (PGR) on shoot bud regeneration from callus cultures of $\mathrm{S}$. chinensis

\begin{tabular}{|c|c|c|c|c|c|c|c|}
\hline \multicolumn{4}{|c|}{$\begin{array}{l}\text { Mean of shooting } \\
\text { response \% }\end{array}$} & \multirow{2}{*}{$\begin{array}{c}\text { Mean of } \\
\text { Shooting } \\
\text { response \% }\end{array}$} & \multirow{2}{*}{$\begin{array}{c}\text { Mean number } \\
\text { of shoot } \\
\text { buds/explant } \\
\text { (cm) } \pm \text { SE } \\
\end{array}$} & \multirow{2}{*}{$\begin{array}{c}\text { Mean height } \\
\text { of shootlet } \\
(\mathrm{cm}) \pm \mathrm{SE}\end{array}$} & \multirow{2}{*}{$\begin{array}{c}\text { Mean number of } \\
\text { Leaves per } \\
\text { explant }\end{array}$} \\
\hline$\overline{\mathbf{B A P}}$ & TDZ & $2 \mathrm{iP}$ & NAA & & & & \\
\hline \multirow[t]{7}{*}{0} & 0 & 0 & 0 & 0.0 & 0 & 0 & 0 \\
\hline & & 0.5 & 0.5 & 35 & $2 \pm 0.57$ & $1.2 \pm 0.2$ & $3.5 \pm 0.1$ \\
\hline & & 1 & 1 & 30 & $1.6 \pm 0.33$ & $1.8 \pm 0.4$ & $3 \pm 0.23$ \\
\hline & & 1 & 0.5 & 40 & $2.3 \pm 0.33$ & $2 \pm 0.11$ & $6 \pm 0.11$ \\
\hline & 0.5 & & 0.5 & 75 & $8 \pm 1$ & $2.8 \pm 0.11$ & $7.5 \pm 0.28$ \\
\hline & 1 & & 1 & 62 & $5.3 \pm 0.33$ & $2.4 \pm 0.1$ & $5.8 \pm 0.23$ \\
\hline & 1 & & 0.5 & 80 & $10 \pm 0.57$ & $3.8 \pm 0.11$ & $11.7 \pm 0.78$ \\
\hline 0.5 & & & 0.5 & 70 & $7 \pm 0.57$ & $3.2 \pm 0.11$ & $5.4 \pm 0.2$ \\
\hline 1 & & & 1 & 60 & $4 \pm 0.57$ & $2.6 \pm 0.11$ & $5 \pm 0.11$ \\
\hline 1 & & & 0.5 & 85 & $12.3 \pm 0.33$ & $3.4 \pm 0.11$ & $7 \pm 0.28$ \\
\hline
\end{tabular}

Table 4: Response of different PGRs (Auxins) on the induction of rooting on half strength MS medium

\begin{tabular}{lllll}
\hline $\begin{array}{l}\text { Concentration } \\
\text { of plant growth } \\
\text { regulators }(\mathbf{m g} / \mathbf{l})\end{array}$ & $\begin{array}{l}\text { Percentage of } \\
\text { explants rooted }(\%)\end{array}$ & $\begin{array}{l}\text { Mean number } \\
\text { of rootlets } \\
\text { per explants } \pm \text { SE }\end{array}$ & $\begin{array}{l}\text { Mean root } \\
\text { length } \pm \text { SE }\end{array}$ \\
\hline Control & 0 & 0.0 & 0 & 0 \\
IBA & 0.5 & 70 & $7 \pm 0.23$ & $2.8 \pm 0.11$ \\
IBA & 1 & 30 & $4 \pm 0.11$ & $2 \pm 0.11$ \\
IBA & 2 & 25 & $2 \pm 0.23$ & $1.8 \pm 0.11$ \\
IAA & 0.5 & 75 & $8.5 \pm 0.28$ & $3 \pm 0.11$ \\
IAA & 1 & 38 & $6 \pm 0.41$ & $2.4 \pm 0.23$ \\
IAA & 2 & 25 & $3 \pm 0.41$ & $2.2 \pm 0.23$ \\
NAA & 0.5 & 28 & $3.4 \pm 0.30$ & $1.9 \pm 0.28$ \\
NAA & 1 & 22 & $2.4 \pm 0.30$ & $1.6 \pm 0.23$ \\
NAA & 2 & 20 & $1.9 \pm 0.2$ & $1.4 \pm 0.23$ \\
\hline
\end{tabular}

The number of explants inoculated per each treatment, mean number of explants showing bud emergence, mean number of explants showing shoot elongation, number of explants rooted and number of explants hardened were listed in Table 5. Opening of small leaves from the shootlets was observed during $4^{\text {th }}$ week (Plate $2 \mathrm{~b}$ ). In few explants, the explant started yellowing from the bottom and the yellowing reached to top, causing death of that explant in 8-9 weeks. Shoots longer than $3 \mathrm{~cm}$, with leaves opened were transferred to half MS rooting media, supplemented with different concentrations of PGRs i.e. IBA $(0.5-1 \mathrm{mg} / \mathrm{l})$ or NAA $(0.5-1 \mathrm{mg} / \mathrm{l})$ or IAA $(0.5-1 \mathrm{mg} / \mathrm{l})$. Maximum number of rooting observed in half MS media supplemented with IAA $0.5 \mathrm{mg} / 1$. small roots were initiated in explants that were grown on BAP $(3.5 \mathrm{mg} / \mathrm{l})+\mathrm{IBA}(1 \mathrm{mg} / \mathrm{l})$ (Plate 2c) where the explants from all other PGRs combinations failed to root and they showed yellowing of leaf and browning of tissue.

\subsection{Seed explant:}

Seed explants cultured on full strength MS medium supplemented with BAP $(1-3 \mathrm{mg} / \mathrm{l})$ with different combinations of PGRs i.e. IAA $(1-3 \mathrm{mg} / \mathrm{l})$ or $2 \mathrm{iP}$ $(2 \mathrm{mg} / \mathrm{l})$ or NAA $(1-3 \mathrm{mg} / \mathrm{l})$. Even at the lowest concentration BAP alone induced adventitious shoot bud from seed explants. However, The seeds showed highest percentage of shoot on MS medium supplemented with BAP $2 \mathrm{mg}+$ IAA $2 \mathrm{mg} / \mathrm{l}$ and BAP $2 \mathrm{mg}+2 \mathrm{iP} 2 \mathrm{mg} / \mathrm{l}$ whereas the former medium induced shoot regeneration after the callusing of the 
explant, the latter stimulated direct shoot formation(Table 6, Plate 3a). The combination of BAP with IAA or NAA exhibited formation of shoot buds. However, the differentiation of shoots was preceded by callusing of the explants. At lower concentration, IAA $(68 \%)$ and NAA (1mg/l) (64\%) direct shoot buds regeneration was observed with an occurrence comparable to BAP $(3 \mathrm{mg} / \mathrm{l})+2 \mathrm{iP}(2 \mathrm{mg} / \mathrm{l})$. Nevertheless, the intensity of shoot bud formation was high with the latter treatment (Table 6). Shoots were then transferred to MS medium containing only BAP $1 \mathrm{mg} / \mathrm{l}$ for well and healthy development. On this medium shoots were well developed and attained height of $2.63 \pm 0.29$ after 20 days (Plate $3 \mathrm{~b})$. For the initiation of roots shoots were individually transferred to MS medium supplemented with NAA $0.5 \mathrm{mg} / \mathrm{l}$. In this treatment $90 \%$ of shoots produced roots directly at the bottom within 7 days, with an average of five roots per explants (Plate 3c).
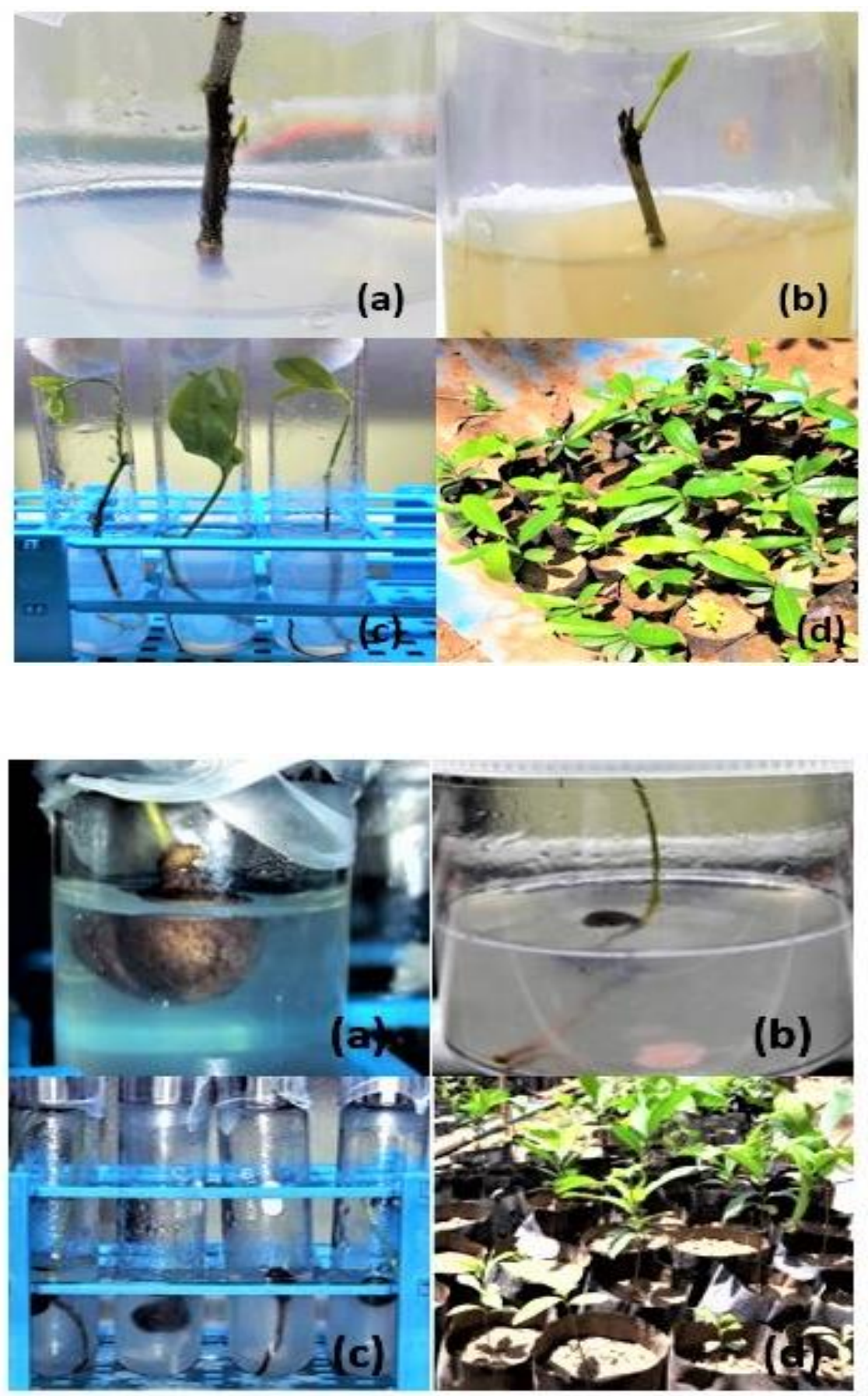

Plate 2: Different stages of micro-propagation of $\mathrm{S}$. chinensis L. using nodal segments:

(a) Bud emergence from axils of nodal explants supplemented with BAP $(3.5 \mathrm{mg} / \mathrm{l})+$ IBA (1mg/l)

(b) initiation of shoot elongation from emerged axillary buds

(c) rooting observed on MS medium supplemented with IAA $(0.5 \mathrm{mg} / 1)$

(d) Acclimatized plantlets with thick roots were transferred to polythene bags

Plate 3: Different stages of micro-propagation of $\mathrm{S}$. chinensis $L$. using seed explants:

(a) shoot bud emergence from seed explant supplemented with BAP $(3 \mathrm{mg} / \mathrm{l})+2 \mathrm{iP}$ (2mg/l),

(b) (c) rooting observed on MS medium supplemented with NAA $(0.5 \mathrm{mg} / \mathrm{l})$

(d) Hardened plants 
Table 5: In-vitro response of nodal segment explants to various concentration of PGR

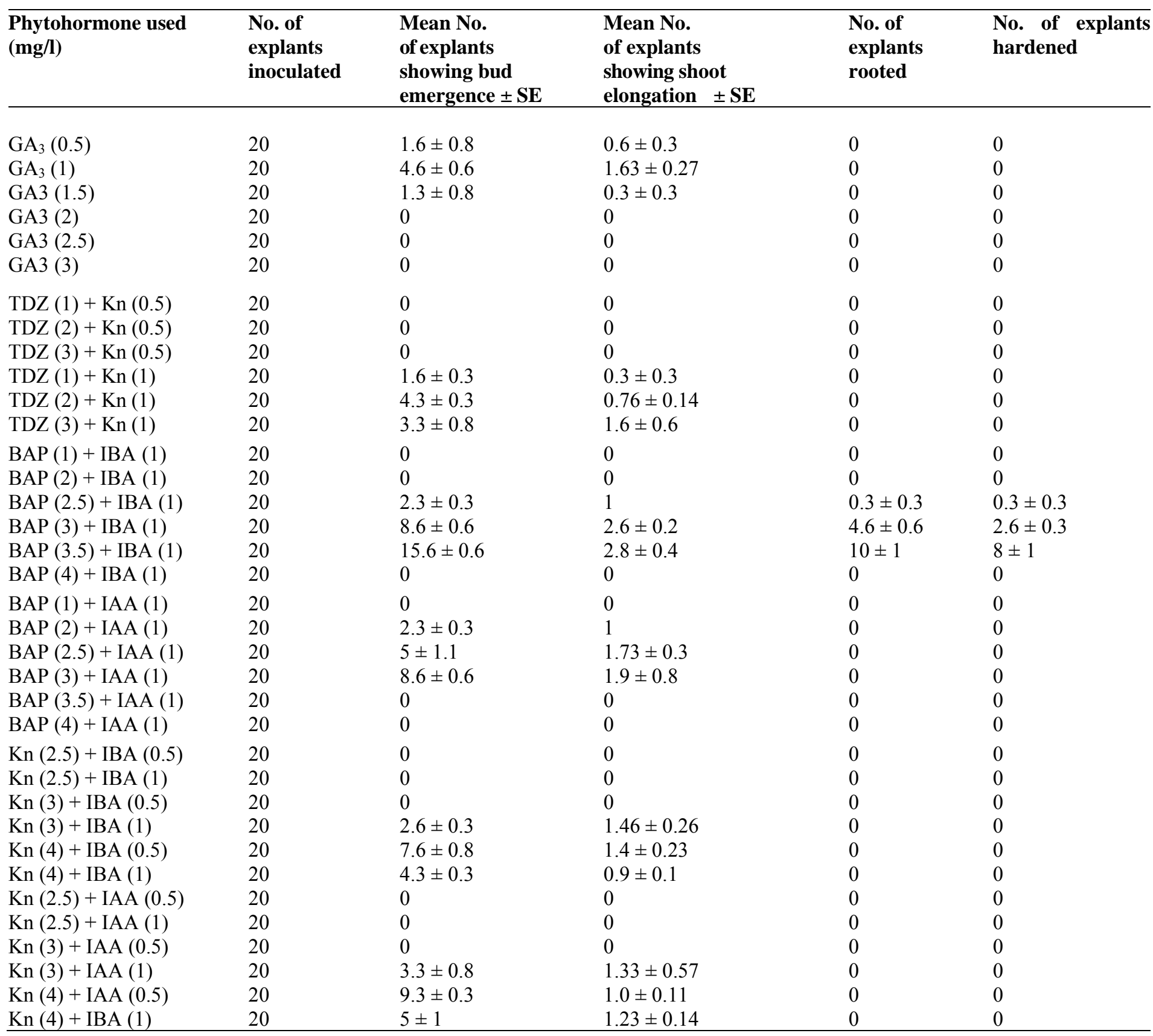

*Significant at $\mathrm{p} \leq 0.05$ level of probability 
Table 6: In -vitro response of seed explants to various concentrations of PGR

\begin{tabular}{|c|c|c|c|c|c|c|c|c|c|}
\hline \multicolumn{4}{|c|}{ No. of explants inoculated } & $\begin{array}{l}\text { No. of } \\
\text { explants used }\end{array}$ & $\begin{array}{l}\text { Percentage of } \\
\text { Seed } \\
\text { germinated (\%) }\end{array}$ & \multicolumn{2}{|c|}{$\begin{array}{l}\text { Percentage of } \\
\text { Culture } \\
\text { with adventitious } \\
\text { shootlet }\end{array}$} & $\begin{array}{l}\text { Mean no. } \\
\text { shootlets } \\
\text { per explants } \pm \mathrm{SE}\end{array}$ & $\begin{array}{l}\text { Mean height } \\
\text { of shootlet } \pm \mathrm{SE}\end{array}$ \\
\hline 1 & & & & 25 & 0 & 20.92 & 0 & $2.43 \pm 0.29$ & $1.46 \pm 0.29$ \\
\hline 2 & & & & 25 & 0 & 25.32 & 0 & $3.33 \pm 0.66$ & $1.7 \pm 0.20$ \\
\hline 3 & & & & 25 & 0 & 33.04 & 0 & $5.33 \pm 0.29$ & $2.0 \pm 0.23$ \\
\hline 1 & 2 & & & 25 & 0 & 41 & 0 & $6.1 \pm 15$ & $2.1 \pm 0.17$ \\
\hline 2 & 2 & & & 25 & 0 & 54.12 & 0 & $6.6 \pm 0.30$ & $2.4 \pm 0.23$ \\
\hline 3 & 2 & & & 25 & 0 & 73 & 0 & $12.3 \pm 0.40$ & $2.63 \pm 0.29$ \\
\hline 1 & & & 1 & 25 & 0 & 68 & 0 & $8.5 \pm 0.28$ & $2.5 \pm 0.28$ \\
\hline 2 & & & 2 & 25 & 99.32 & 0 & 64 & $7.33 \pm 0.35$ & $2.0 \pm 0.1$ \\
\hline 3 & & & 3 & 25 & 94.64 & 0 & 60 & $6.1 \pm 0.20$ & $1.9 \pm 0.1$ \\
\hline 1 & & 1 & & 25 & 0 & 32.24 & 0 & $5.13 \pm 0.29$ & $1.83 \pm 0.12$ \\
\hline 2 & & 2 & & 25 & 82.5 & 0 & 32 & $4.8 \pm 0.24$ & $1.6 \pm 0.32$ \\
\hline 3 & & 3 & & 25 & 75 & 0 & 28.2 & $4.6 \pm 0.23$ & $1.5 \pm 0.36$ \\
\hline
\end{tabular}

After 5 weeks of incubation in light, the rooted shoots were carefully removed from culture vessels and washed in running tap water to free agar. Healthy rooted shoots were transferred to plastic cups containing sand: soil: vermiculite in the proportion of $(1: 1: 1)$ and covered with polythene covers to maintain humidity under aseptic conditions inside the culture room. After 2 weeks the bag was carefully removed and transferred to earthen pots with garden soil (plate $1 \mathrm{f}, 2 \mathrm{~d}$ and $3 \mathrm{~d}$ ).
3.4 GC-MS and HPLC-MS analysis of leaf and callus extract of $S$. chinensis

S. chinensis leaf methanolic extract were analysed using GC-MS technique, their chemical composition showed 20 components. Table 7 and Figure 1a shows that most copious component is phytol.

Table 7: Comparison between phyto-components identified in methanol extract of leaf parts and callus obtained from $S$. chinensis using GC-MS peak report TIC

\begin{tabular}{lcc}
\hline IUPAC name; molecular formula & \multicolumn{2}{c}{ Area \% } \\
\cline { 2 - 3 } & Leaf & Callus \\
\hline & & \\
Phenol, 2,4-bis(1,1-dimethylethyl)-; $\mathrm{C}_{14} \mathrm{H}_{22} \mathrm{O}$ & 7.42 & 6.11 \\
Octadecane; $\mathrm{C}_{18} \mathrm{H}_{38}$ & -- & 0.39 \\
3-Hexadecanol; $\mathrm{C}_{16} \mathrm{H}_{34} \mathrm{O}$ & -- & 0.59 \\
Neophytadiene; $\mathrm{C}_{20} \mathrm{H}_{38}$ & -- & 2.35 \\
3,7,11,15-Tetramethyl-2-hexadecen-1-ol; $\mathrm{C}_{20} \mathrm{H}_{40} \mathrm{O}$ & -- & 0.83 \\
3-Heptadecanol; $\mathrm{C}_{17} \mathrm{H}_{36} \mathrm{O}$ & 1.09 & -- \\
Hexadecanoic acid, methyl ester; Methyl hexadecanoate & 1.64 & 1.73 \\
Hexadecanoic acid; $\mathrm{CH}_{3}\left(\mathrm{CH}_{2}\right)_{14} \mathrm{COOH} ;$ & 16.37 & 5.04 \\
Cyclohexanol, 1-butyl-; $\mathrm{C}_{10} \mathrm{H}_{20} \mathrm{O}$ & -- & 0.39 \\
9,12,15-Octadecatrienoic acid, methyl ester, $(\mathrm{Z}, \mathrm{Z}, \mathrm{Z})-; \mathrm{C}_{19} \mathrm{H}_{32} \mathrm{O}_{2} ;$ & -- & 1.28 \\
Phytol; $\mathrm{C}_{20} \mathrm{H}_{40} \mathrm{O}$ & 29.69 & 14.12 \\
Tetratriacontane; $\mathrm{C}_{34} \mathrm{H}_{70}$ & -- & 1.26 \\
Tetracosanoic acid, methyl ester; $\mathrm{C}_{25} \mathrm{H}_{50} \mathrm{O}_{2}$ & 1.37 & -- \\
cis,cis,cis-7,10,13-Hexadecatrienal; $\mathrm{C}_{16} \mathrm{H}_{26} \mathrm{O}$ & 3.45 & -- \\
Octadecanoic acid; $\mathrm{C}_{17} \mathrm{H}_{35} \mathrm{CO}_{2} \mathrm{H}$ & 2.33 & 0.53 \\
Hexadecanoic acid, 2-hydroxy-1-(hydroxymethyl)ethyl ester; $\mathrm{C}_{19} \mathrm{H}_{38} \mathrm{O}_{4}$ & 27.26 & 8.95 \\
Squalene; $\mathrm{C}_{30} \mathrm{H}_{50}$ & 2.34 & 40.32 \\
dl-.alpha.-Tocopherol; $\mathrm{C}_{29} \mathrm{H}_{50} \mathrm{O}_{2}$ & -- & 15.60 \\
Octadecanoic acid, 2,3 -dihydroxypropyl ester & 7.04 & -- \\
(Z,Z)-6,9-CIS-3,4-Epoxy-nonadecadiene & -- & 0.52 \\
\hline
\end{tabular}




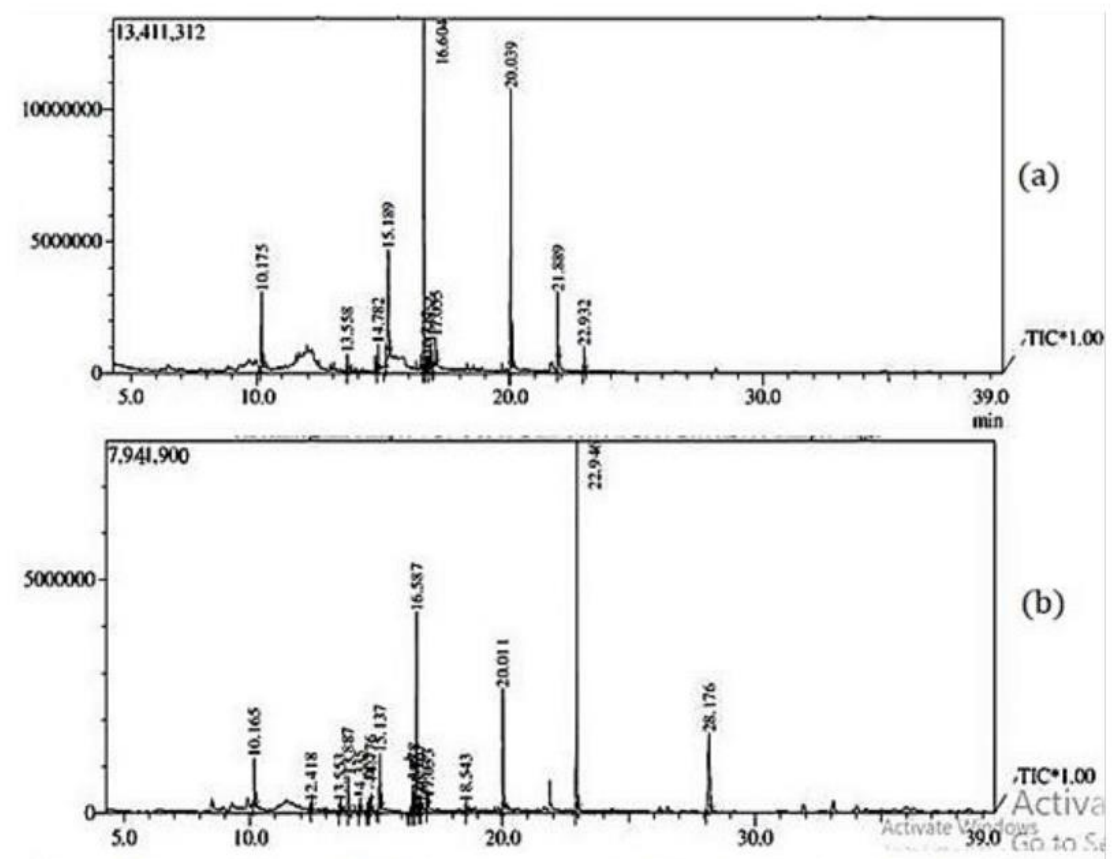

Figure 1: Representative of GC-MS chromatograms of leaf (a) and callus extract (b) of S. chinensis

HPLC analysis has shown the presence of mangiferin in both leaf and callus extracts of S. chinensis (Figure 2). The study showed that $S$. chinensis callus extract $(26 \mathrm{mg} / \mathrm{ml})$ contain higher quantity of mangiferin as compared to leaf extract $(4 \mathrm{mg} / \mathrm{ml})$ (Figure 3$)$.
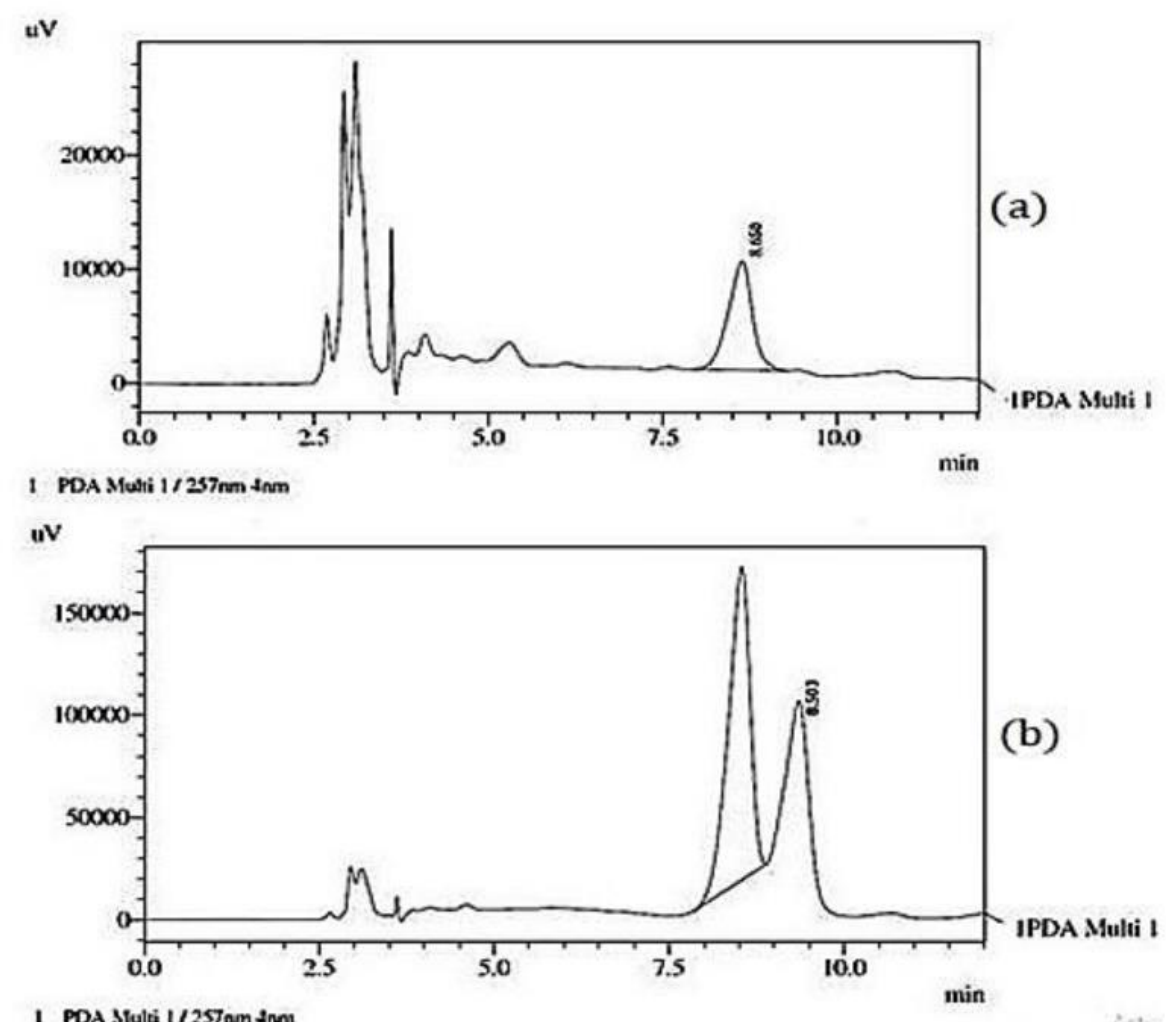

Figure 2: Representative of HPLC-MS chromatograms of leaf (a) and callus extract (b) S. Chinensis 
Table 7 and Figure 1b shows that the most abundant compound is squalene. The extract also contains hexadecanoic acid (5.04\%), Phenol, 2, 4-bis(1,1dimethylethyl) (6.11\%), squalene $(40.32 \%)$. Phytochemical dl-.alpha.-Tocopherol $(15.60 \%)$ was found only in callus and has great therapeutic value. The extract also contains hexadecanoic acid (16.35\%), Phenol, 2, 4-bis(1,1-dimethylethyl) $(7.45 \%)$, squalene $(2.38 \%)$ as major components. The chemical composition of callus extract of $S$. chinensis showed 16 components.

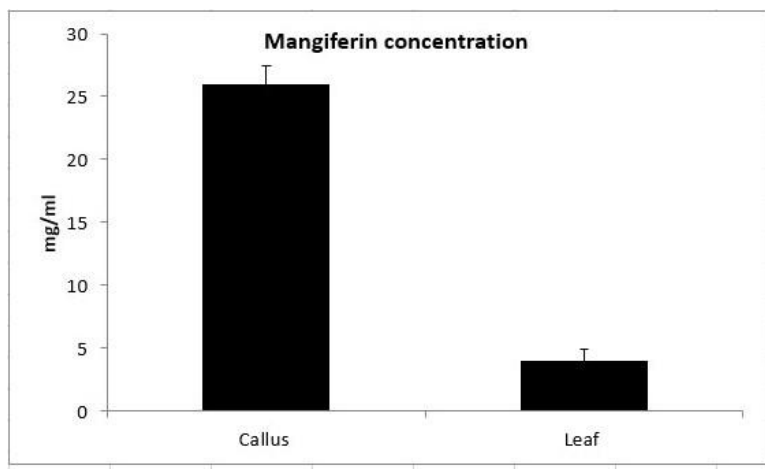

Figure 3: Comparison of Mangiferin concentrations $(\mathrm{mg} / \mathrm{ml})$ in the methanol extracts of the stem and root parts of Salacia species.

\section{Discussion}

The present study comprehensively investigated the effects of various kinds and concentrations of PGRs on 3 different explants of $S$. chinensis micropropagation. The ability to regenerate complete plants from mature leaf derived callus, nodal segment and seeds of $S$. chinensis has been found.

Leaf explants and nodal explants are the most suitable plant source for regeneration. BAP among the different cytokinins that have the higher potential for both shoot and root induction and IAA for root initiation among the auxins (Elangomathavan et al., 2017). An increase in the auxin concentration with the higher concentration of cytokinins resulted in the production of callus at cut ends of leaf segments, proliferation of shoot and root for the leaf derived callus, nodal segment and seed explants which may be due to the cell proliferation stimulated by the accumulation of auxins in the presence of cytokinins (Marks and Simpson 1994; Dhanshri et al., 2015). In the present study, cytokinins promoted intensive shoot multiplication. Cytokinins are reported to overcome apical dominance, induce high number of shoot buds and also release lateral buds from dormancy (Rout et al., 2000; Rout, 2005).

The MS medium supplemented with BAP $3.5 \mathrm{mg} / \mathrm{l}$ + IBA $1 \mathrm{mg} / \mathrm{l}$ and NAA $0.5 \mathrm{mg} / 1$ +TDZ $0.5 \mathrm{mg} / 1$ resulted highest number of shoot elongation and root formation. The negative effect on shoot regeneration was observed when the MS medium supplemented with BAP $4 \mathrm{mg} / \mathrm{l}$ and continued exposure of explants to high concentration of BAP during shoot induction inhibited the growth of shoots. The results of the present study are in accordance with Deepak et al., (2015) with the use of BAP for shoot multiplication. The presence of auxins at lower concentration in medium facilitated better root formation. MS medium supplemented with $15 \mathrm{mg} / \mathrm{l}$ IAA was found superior to IBA and NAA in inducing roots.

In our previous study we have analysed the phytoconstituents and mangiferin concentration in different species of Salacia (Kamat et al. 2019). We have noticed that the leaf, stem and root extract of $S$. chinensis showed the higher concentration of mangiferin compared to other species. Although many compounds were reported from different species of Salacia, it is an eminent fact that mangiferin is important for its antidiabetic property and is a well explored molecule in in vitro and preclinical studies. Mangiferin projected to be the most active principle from Salacia spp.

The anti-inflammatory activity and anti-arthritic activity of 9,12-octadecadienoic acid were reported (Murray 2012). The anti-inflammatory, antimicrobial, and antioxidant activity of phenol, neophytadiene, 9,12-octadecadienoic acid and dl.alpha.-Tocopherol were reported (Frank 1962; Owen et al., 2000; Maruthupandian and Mohan 2011). Based on the literature, above compounds could effectively contribute to the antibacterial activities of selected plants.

The phenolic compounds are known to be synthesized by plants in response to microbial infection. It is therefore possible that they can act as effective antimicrobial substances against a wide array of microorganisms. However, the antimicrobial activity of plant extracts depends not only on phenolic compounds but also by the presence of different secondary metabolite (Gordana et al., 2007) like hydroxyl groups on the active constituents, because these substances are capable of binding to bacterial adhesions and interacting with the supply of receptors on the surface. The phenolic compound observed in this study is phenol, 2,4-bis (1,1-dimethylethyl) in natural as well as callus extract.

\section{Conclusions}

In the present study, the successful protocol for callus induction and shoot regeneration from leaf derived callus of $S$. chinensis has been established. About 64\% seeds exhibited regeneration. Leaf 
explants and nodal segments are the most suitable plant materials for regeneration. The protocol presented in this study may provide a high efficiency regeneration system for successful regeneration of adventitious shoots for ex situ preservation of $S$. chinensis as well as genetic improvement studies for pharmaceutical uses and future research investigations. This optimized protocol helps in providing a promising method for the large scale propagation of this species. Like mangiferin, other compounds identified in leaf and callus extract have their own biological importance and further study of this plant's phytochemicals by in silico and in vitro methods can prove its medicinal importance in future and can be effective and efficient drug source.

\section{Acknowledgement}

This research did not receive any specific grant from funding agencies in the public, commercial, or notfor-profit sectors.

\section{References}

Bhagya, N., Sheik, S., Sharma, M.S., Chandrashekar, K.R. (2011) Isolation of endophytic colletotrichum gloeosporioides penz. From Salacia chinensis and its antifungal sensitivity. Journal of Phytology 3(6):20-2.

Deepak, K.G.K., Suneetha, G., Surekha (2015) In vitro clonal propagation of Salacia oblonga WALL an endangered medicinal plant. Annals of phytomedicine 4(2): 67-7

Dhanasri, G., Srikanth, R.M., Naresh, B., Pratibha, Devi. (2015) Molecular genetic analysis of Salacia reticulata, a threatened medicinal plant for the study of genetic diversity. International Journal of Pure and Applied Bioscience 3(1): 9299.

Elangomathavan, R., Beaulah, N., S, Hariharan., P, Kalaivanan. (2017) Indirect shoot organogenesis from leaf explants of threatened medicinal plant Cleistanthus collinus. International Journal of Advanced Research in Biological Sciences 4(1):58-68.

Frank, D. Popp. (1962) Synthesis of Potential Anticancer Agents. VIII. Benzaldehyde Mustard Derivatives and Related Compounds Journal of Medicinal Chemistry 5 (3):627-629.

Ghanam, K., Srivastava, V., Deshpande, J., Juturu, V. (2016) Salacia chinensis extract (SCE) modulates carbohydrates and lipid metabolism: in vitro and in vivo models. International Journal of Endocrinology and Metabolism: 3(6): 1-8.

Herbarium JCB. Flora of Karnataka. Indian Institute of Science. florakarnataka.ces.iisc.ac.in.

IUCN red list of threatened species (2015). www.iucnredlist.org

Jayaraj, R., Sasidharan, N., Beenu, T., Muhammad, A. 2016: Comparative phytochemical profiling and quantification of mangiferin content in species of Salacia from Southern Western Ghats of India. Journal of Biologically Active Products from Nature., 6(3): 209-222.

Kamat, S.G., Vasudeva, R., Patil, C.G. (2019) GCMS and LC-MS based phytochemical profiling and quantification of mangiferin in six species of Salacia from the Western Ghats of India. South Asian Journal of Experimental Biology 8(4):132148.

Maheswari, J. (2011) Patenting Indian medicinal plants and products. Indian Journal of Science and Technology 4(3):298-301.

Majid, B.N., Sampath, K.K.K., Prakash, H.S., Geetha, N. (2016) Rapid mass propagation of Salacia chinensis L., an endangered valuable medicinal plant through direct organogenesis. Indian Journal of Science and Technology 9(4).

Marks, T.R., and Simpson, S.E. (1994) Factors affecting shoot development in apically dominant Acer cultivars in vitro. Journal of Horticultural Science 69: 543-551.

Maruthupandian, and V, R. Mohan. (2011) GC-MS analysis of some bioactive constituents of Pterocarpus marsupium Roxb. International ournal of. Chemtech. Research. 3 (3), 1652-1657.

Matsuda, H., Yoshikawa, M., Morikawa, T., Tanabe, G., Muraoka, O. (2005) Antidiabetogenic constituents from Salacia species. Journal of Traditional Medicine: 22 (1):145-53.

Murashige, T. and Skoog, F. (1962) A revised medium for rapid growth and bio assays with tobacco tissue culture. Physiologia plantarum 15:473-497.

Murray, J.A.H., Jones, A., Godin, C., Traas, J. (2012) Systems analysis of shoot apical meristem growth and development: integrating hormonal and mechanical signalling. Plant Cell 24:39073919

Patwardhan, A., Pimputkar, M., Joshi, R. (2014) Evaluation of anti-diabetic property of extracts of different plant parts of Salacia chinensis Linn. Journal of Biodiversity, Bioprospecting and Development 1:107.

R.W. Owen, A. Giacosa, W.E. Hull, R, Haubner., B, Spiegelhalder., and H, Bartsch. (2000) the antioxidant/anticancer potential of phenolic compounds isolated from olive oil. European Journal of Cancer 36(10):1235-47.

Rout, G.R. (2005) Micropropagation of Clitoria ternatea Linn. (Fabaceae) -An important medicinal plant. In vitro Cellular and Developmental Biology. Plant 41:516-519.

Rout, G.R., Samantaray, S., Das, P. (2000) In vitro manipulation and propagation of medicinal plants. Biotechnology Advances 18:91-120.

S, C. Gordana., M, C. Jasna., M, D. Sonja. (2007) Antioxidant potential, lipid peroxidation inhibition and antimicrobial activities of Satureja montana L. Subsp. kitaibelii extracts. 
International Journal of Molecular Science 8:1013-1027.

Sikarwar, M.S., and Patil, M.B. (2012) Antihyperlipidemic activity of Salacia chinensis root extracts in triton-induced and atherogenic diet-induced hyperlipidemic rats. Indian Journal of Pharmacology: 44(1): 88-92.

Sivakumar R, Dhivya A (2015) GC-MS analysis of bioactive compounds on ethyl acetate extract of Cordia Monoica Roxb. Leaves. IJRDPL 4(1): 1328-1333.

Waltenberger, B., Mocan, A., Smejkal, K., Heiss, E.H. (2016) Natural products to counteract the epidemic of cardiovascular and metabolic disorders. Molecules 21:807. 